\title{
Defining Family Principle In Business Activities In Indonesian Legal System Based On Pancasila
}

\author{
Teuku Ahmad Yani ${ }^{1}$, Tan Kamello ${ }^{2}$,Husni Jalil ${ }^{3}$, ImanJauhari. ${ }^{3}$ \\ ${ }^{I}$ PhD student at Faculty of Law, Syiah Kuala University, Indonesia ${ }^{2}$ Main supervisor, Syiah Kuala University, \\ Indonesia ${ }^{3}$ Supervisor, Syiah Kuala University, Indonesia.
}

\begin{abstract}
Business activities in Indonesia consider family principle as an important aspect because this principle is the character of Indonesian life. Family principle comprises two values, i.e. mutual assistance and deliberation, as a depiction of Pancasila, the ideology of Indonesian people. These two pillars have become the main characteristics of Indonesian culture, which has the value of collectivism. Other values are applicable in other legal systems in Indonesia, such as in a memorandum of understanding, as long as they are in line with the two values of family principle.
\end{abstract}

Keywords: family principle, business, Pancasila

\section{INTRODUCTION}

The 1945 Constitution is the Indonesian constitution which upholds family principle as a legal principle in Indonesian economic system(Purnama, 2010, p. 256). The 1945 Constitution is a reference for lower rank regulations(Syauki, 2011, p. 53). The significance of the 1945 Constitution is because the Constitution functions as a constitution in civil law to actualize the welfare state(Asshidiqie, 2010, p. 214).

Indonesian Constitutional Court, in its Decree No. 28/PUU-XI/2013, explicitly states that family principle is a character economic system as the original principle of law in Indonesia, which is based on Indonesian culture. This principle needs to be depicted into law and regulations so that it can play a significant role in Indonesian politics in the economic sector.

Economic sector is a genus, thus has a broad dimension, which according to Muhammad (2010, p. 11), covers business managed by public as its species of economic activities. Therefore, the business managed by the people should refer to Indonesian political system, as regulated in Pancasila.Business activities conducted by society are not separated from the law because they are unable to fulfil they need without working with others. Cooperation between law subjects in business activities is not only recognised in Indonesia, but it is also found in all countries based on their own legal systems. Indonesia has its own legal system known as Pancasila, where family principle is valued at its best. Therefore, regulations for business should be based on the family principles.

Family principle as a part of principles in Indonesia as a constitutional state was challenged by many over liberalism and capitalism, which are individualistic in the systems of civil law and common law. On the other hand, civil and common legal systems have influenced Indonesian legal system. Therefore, the family principle should not only be written in the constitution, but it also has to be understood by every component of the state, and even by foreign countries.

Family principle which becomes the legal framework for managing a business should be researched in detail so that the difference between Indonesian legal framework and liberalism, as well as capitalism, among from their similarities. Understanding their differences and similarities is essential because its concrete implementation in various business activities depends on it.

Lack of understanding of these differences and similarities is a concern to legal experts such as BagirManan, a professor of law at Padjajaran University, Bandung, Indonesia, and the chairman of Indonesian Supreme Court, who claimed that many laws in Indonesia are not in line with the family principle(Manan \& Harijanti, 2014, p. 183). Moreover, Manan(2013, p. 21) states that family principle is still a mere illusion. In addition, Ruslina(2013, p. 27) explicitly reported that many laws are not in line with the constitution. Therefore, Wiko cited in Arinanto andTriyanti(2009, p. 7) admitted what most people claimed that the development of law in Indonesia has not been completed is not untrue.

Pursuant to the discussion above, a study aimed at finding out the meaning delivered by family principle, and the position of family principle over principles of other legal systems which have recently influenced legal system in Indonesia was urgently required.

This research employed normative legal research method, i.e. a research which refers to principles, norms of laws, international conventions, treaty, court decisions and norms of social life. Therefore, this 
research wasa descriptive research because it involved a process of investigating and finding principles, regulations, values, and doctrines to respond to the existing legal matters.

In addition, the approach used in this research was a statute approach, and conceptual approach, by analysing primary, secondary, and tertiary data. The data were analysed qualitatively to understand the meaning of the collected legal materials, and later interpreted normatively, logically, and systematically by usingdeductivemethod.

\section{a. Pillars in family principle as representation of Pancasila}

\section{DISCUSSION}

Family principle is the legal framework in Indonesia, in accordance with Pancasila as the official philosophical foundation of Indonesia. This principle distinguishes Indonesia from other countries (Kaelan, 2013, p. 74). This uniqueness should be depicted in legal system for business activities in Indonesia, which is distinguishable from laws in other countries(Sundari, 2014, p. 1).

Cicero, a philosopher, states that where there is a community, the law is law there (ibis societasubiius); therefore, it is undeniable that a business activity requires specific laws. In addition, as suggested by Von Savigny as cited Gilsen and Gorle(2005, p. 15), an effective law should be in line with the national character or spirit of the people (volksgeist).

Indonesia, as a country with a specific ideology, is distinct from other countries. Even after the colonisation by the Netherlands for 350 years, Pancasila is still the ideology which grows and develops in the heart of Indonesian people.The survival of Pancasila was due to variety in terms of languages, tribes, cultures, and religions in Indonesia. This variety has given the character to Indonesian people and influences the thought of Indonesian founders. Therefore, Pancasila contains values embraced by Indonesian citizens.

Notonagoro(1975, p. 17) states that Pancasila was established by three values, i.e. customs, cultures, and religions, that are a way of life, spirit, and personality of Indonesian people. Those values were resources for Pancasila. They were formulated into state values and later developed into Pancasila. Although values do not always represent behaviours in culture, they can explain on what an action is based(Kaelan, 2013, p. 309).

The existence of Pancasila as the personality of Indonesian people is due to the fact that the identity of Indonesia is an accumulation of identities of the people, which become cultures in Indonesia(Latief, 2012, p. 78), so that Pancasila becomes a rational principle(Mahmud, Halim, \& Kattani, 2004, p. 63) for Indonesian people. In addition, Pancasila is a supreme symbol which distinguishes Indonesian people from those of other countries.

The state personality is applicable in various aspects for people, country and community (including in business sector), as presented in the following:

(1) Principle 1, Belief in the one and only God. Economic growth is generated by economic and social motivation.

(2) Principle 2, Just and civilised humanity. All people have a strong will to actualize egalitarian, in accordance with values of humanity.

(3) Principle 3, The unity of Indonesia. The priority of economic policy is to create firm national economy, suggesting that nationalism is the foundation of every economic policy.

(4) Principle 4, Democracy guided by the inner wisdom in the unanimity arising out of deliberations amongst representatives. Cooperation is the pillar of the economy and a concrete of mutual business.

(5) Principle 5, Social justice for all of the people of Indonesia. There is clear balance between national-level and centralized planning in implementing economic activities to reach economic and social fairness (Mubyarto, in Oesman \& Alfian, 1991, p. 241).

Every principle in Pancasila has values but it is not independent. All principles are related, to become one. In the Principle 1, Indonesia recognises religions, where one citizen is entitled to one religion. With this principle, religious values hold the highest position in the country, and according to Mubyarto as cited in Oesman and Alfian(1991, p. 241) the consequence is that every regulation does not contradict with the value of belief in the one and only God. According to $\mathrm{Hatta}(1979$, p. 28), this principle leads us to truth, justice, kindness, honesty and brotherhood. The position of belief in the one and only God which is in the first principle is closely related to Islamic teaching which states that the most noble person is the one who is the most pious. Therefore, Pancasila as the philosophical foundation of the state adopted the value of harmony and balance, both in living as a person and as a member of society.

The second principle in Pancasila, just and civilised humanity, is based on the first principle, and becomes the basis for the third principle. This second principle comprises ambitions related to humanity based on the human nature.Related to humanity, especially those related to basic human rights, Soepomo(in Kusuma, 2004 , p. 367) claimed that a country which integrates family values should address all sides of human life, not only economic and social factors, but also politic and government. 
The value implied in just and civilised humanity is always applied in Indonesian development(Notonagoro, 1975, p. 92), including economic development. This value should be realized from human values (Driyarkara, 1980, p. 71). Justice and civilised are moral values of Indonesia people, which becomes a reference in preparing new regulation. According to Bentham as cited in Manan(2005, p. 23) law and moral are two integrated entities. The law should value morality, and morality should be regulated by law, considering moral is one of the primary sides of human life.

The word $a d a b$ 'attitude' is correlated to the terms civilization for Indonesian people who do not hold the principle of individualism but collectivism. This point of view is adopted for interaction in groups, societies, communities and country.

Indonesia adopted this point of view against individualism, and it is called family principle (Wahjono, 1989, p. 16). The basic difference between viewpoints of an individualist and collectivist is that the individualist emphasizes on individuals while collectivist concerns more on the community. However, for a collectivist, who lives with family principle, when an individual deals with community, human dignity is valued the most (Wahjono, 1989, p. 16). The second principle of Pancasila, according to Susanti cited in Erawaty, Hardjowahono, and Susanti(2011, p. 275), is outlined into some values, i.e. justice and equity, and proportionality.

Principle 3, the unity of Indonesia, composed of two words, i.e. unity and Indonesia. The unity of Indonesia is a symbol which shall be implemented by each and every Indonesian citizen in all sectors, including in business activities. From the principle of unity, the first pillar of family principle is the action of helping one another to achieve mutual benefit.

This first pillar is found in many laws in Indonesia, such as laws regarding cooperatives, laws regarding micro, small, and medium business, laws regarding trading, laws regarding insurance, and laws regarding national social security system. The concept of this first pillar is completely different to capitalist viewpoints, where production is to be improved and people are given freedom to get rich as efforts to eradicate poverty.

Theoretically, in capitalism, economic growth is the focus, rather than equity and justice. Therefore, in capitalist society, the authorities are capital owners, so policies they make always benefit themselves, which trades equity of income for many people.

In addition, there is another ideology called liberalism, which is a political philosophy which advocates individual rights and restricts government. This ideology believes that individuals should be given freedom to do whatever they feel like as long as they do not violate other people's rights(Suherman, 2012, p. 45) and this belief established the principle of unrestricted freedom of contract. Western economic philosopher, Adam Smith as cited in Rahardjo(2015, p. 245) emphasized that common kindness does not start from motivating a person to be kind to others, but from an effort to earn a living by giving freedom to every individual to make efforts and compete in a free trade system. Capitalism system consists of three general principles, i.e. individualism (selfinterest), liberalism, and free competition. Those principles are considered as liberal economic system and free market competition system.

Western legal system is also based on principles of secularism and materialism, which is a result of a dichotomy between Divine laws and human law. Theory of laws develops based on society dynamics influenced by the development of knowledge and technology. Theory of laws does not only show cosmological order and its time, but it also motivates changes in viewpoints following the changes of the era. Therefore, theory of laws is not autonomous, but it is dependent and related to other fields of study, which is based in changes of the era(Muntaha, 2014, p. 91).

Indonesia as a country which does not use the principle of capitalism in the economy, it is obliged to participate in laws regarding economic system. This obligation is stated in Constitution, such as paragraph (1) Article 33 of the 1945 Constitution which emphasizes that "The economy shall be organized as a common endeavour based upon the principles of the family system."

The expression of "The economy shall be organized" as stated in the paragraph (1) above, according to Sri Edi Swasono as cited in Oesman and Alfian(1991, p. 245) suggested that economic restructuring and reformation are required. The phrase implies that the economy needs to be organized, not to let it be organized. If laws regarding economy are organized without intervention, it is trade law which is complied, as in liberal and capitalist economic system.

Regarding Principle 4, Democracy guided by the inner wisdom in the unanimity arising out of deliberations amongst representatives, Kartohadiprodjo(2010, p. 171) states that the objective of Principle 4 is to find out "unity among differences, differences in unity". The value of deliberation, according to Susanti as cited in Erawaty et al. (2011, p. 280), is the core of the Principle 4 and the second pillar of the family principle. Deliberating means an action which involves a relationship with others and brings messages. Deliberation is aimed at finding just solutions to a problem without disadvantaging anyone.

The second pillar of the family principle in laws can be found in Law regarding the establishment of laws and regulations. According to this law, the establishment of any law should be based on deliberation, which 
shows that the second pillar of the family principle shall be a part of a process intended for mutual interest in business activities.

By combining the first pillar, i.e. helping each other, and the second pillar, deliberation, we can avoid coercion from a stronger party, because the party has more capital for example. The power of the two pillars can establish business activities which are able to actualize shared idea to help each other based on the value of justice.

Although in the concept of civil law, the word "agree" to establish a contract or a memorandum of understanding, this word implies a sense of competition so that bargaining power among parties who are individualism involved is more prominent compared to how a collectivist thinks, i.e. to help each other.

The strength of the second pillar of family principle lies on shared awareness and spirit in completing a work without focusing on self-interest but on the interest of all people. Family is brotherhood(Swasono, 1987, p. 1 ), which is a statement with a responsibility to ensure mutual interest, progress, and prosperity, as suggested by the meaning of brotherhood which emphasizes on harmony and solidarity.

Swasono(1987, p. 3) citing Muhammad Hatta states that economy which is based on collectivism matches with Indonesian people, who are accustomed to helping each other. There is no opposition between the people and the state. A state is a tool for the people to complete public security.

Kartohadiprodjo(2010, p. 172) states that the objective of the Principle is to find out similarity for different opinions, to establish unity. In running a business which involves many people, deliberation is a bond which results in common opinion to respect one another.

Principle 5 is social justice for all of the people of Indonesia. Justice ranks highest in law (Dimyati, 2014, p. 19), which is accomplished through intention to help each other based on the deliberation. Justice is the primary element of human life, so that Ulpianus, a judge in Roman Empire, in Ibrahim (2006, p. 3), states that "Iustitiaestconstent et perpetuavoluntasiussuumcuiquetribuendi" meaning justice is a permanent, unending intention to give all people their rights.

Based on values in principles of Pancasila and their application for family principle, it is obvious that Indonesia does not only consider family principle as the legal framework but also make them laws which can be applied and practiced. Family principle shall be the primary principle in economic activities, as a reflection of values, both cultural and religion values; therefore, Pancasila has become a motivating factor for economic growth(Rahardjo, 2015, p. 300).

\section{b. Relationship between family principle and other principles in contract law for business}

Pancasila and the 1945 Constitution expect that business is run by following family principle. This principle should be implemented by laws(Asshidiqie, 2014, p. 4). The expression of "Economy shall be organized" as in paragraph (1) of Article 44 of the 1945 Constitution requires an economic restructuring and reformation in law, which is based on family principle.

The Article 33, paragraph (1) requires that family principle is considered higher and used as a framework for other laws regarding business activities. Although there are other principles, they shall be in line with family principle. In addition, contracts made by business players, both with other business players and customers, should refer to family principle. The position of family principle among other principles in laws and contract is presented in the following hierarchical pyramid.

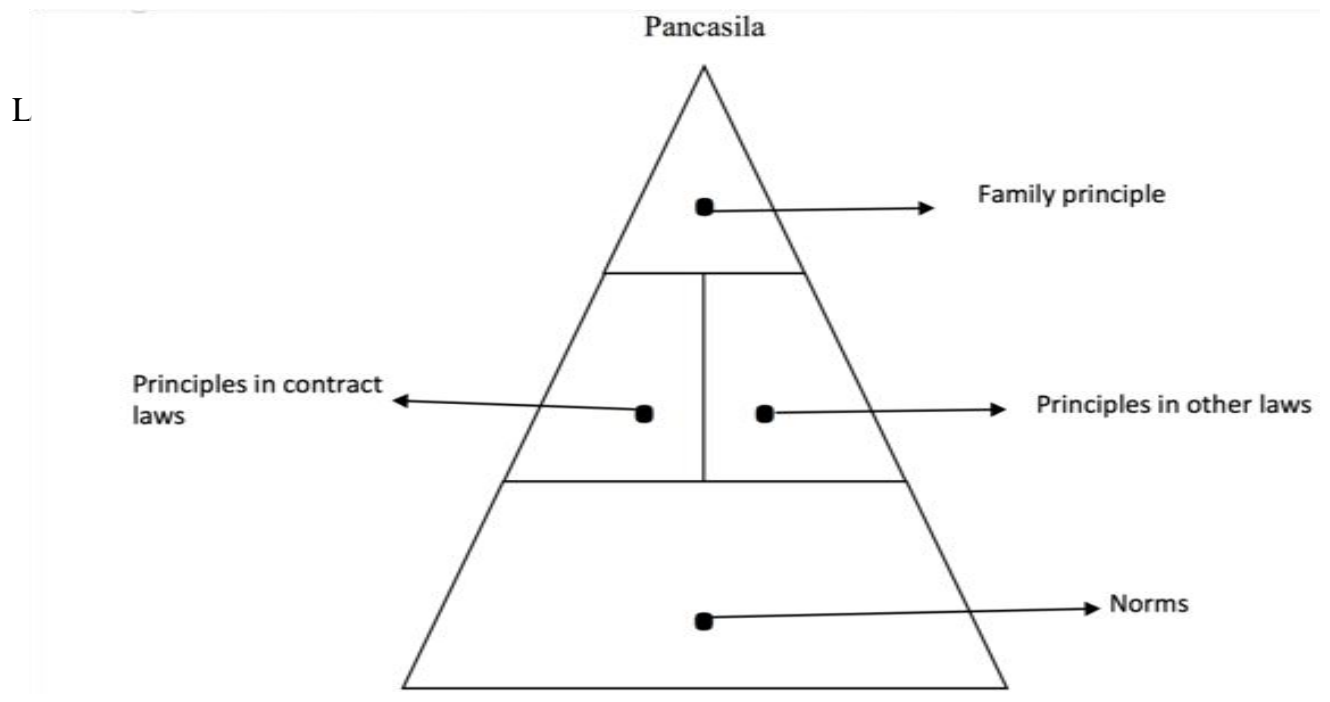


aws and contracts in Indonesia shall be based on family principle. However, some laws regarding business activities in Indonesia do not comply with this requirement, they bring the values left by Dutch Empire. Although the government has made efforts to formulate national law, it is not yet thorough. The law only underwent partial changes or repeals in certain parts of the codified law.

The establishment of the new law was not able to cover most fundamental components in the field of business, i.e. contract. The failure of legal intellectual actors in changing the two codified laws has necessitated Indonesian people to make contracts by using Dutch colonial norms.

The failure to form national laws in the field of contract has resulted in the establishment of contracts by business players who shall refer to 2 codified laws left by the Dutch Empire, i.e. Civil Code and Commercial Code.

Commercial code is a derivative of Civil Code, so that it is a lexspecialis of Civil Code, which is more general. In running business activities, the Civil Code becomes a general guideline as long as the activities do not conflict with Commercial Code. The two codified law consist of the values of liberalism(Wahjono, 1989, p. 15) which are different to those of Pancasila, which is based on family principles. Therefore, the values in both Civil Code and Commercial Code are different to laws mandated by Article 33, paragraph (1) of the 1945 Constitution.

The failure of legal intellectual actors in putting family principle in its position is also evident from the focus of discussion in academic works. The existence of principles in Civil Code and Commercial Code still dominates writers in literature. Badrulzaman(1994, p. 41) states that there are many principles in contract law, i.e. consensualism, equity, moral, custom, benefit, legal certainty, etc.

Niewenhuis as cited in Hernoko(2010, p. 105) proposed three major elements of law contract, i.e. the principle of freedom of contract, the principle of the legal binding of contract, and the principle of binding only parties involved in the contract. In addition, the conclusion of a seminar on "Reformation of Civil Code" hosted by National Law Development Centre (BPHN) in 1981, as reported by Hernoko(2010, p. 10), listed the following legal principles in a contract.

a. The principle of freedom of contract;

b. The principle of protection for less fortunate people;

c. The principle of good deed;

d. The principle of harmony;

e. The principle of morality;

f. The principle of public interest;

g. The principle of legal certainty; and

h. The principle of pacta sun servanda(the sanctity of contracts)

Budiono and Moeliono(2006, p. 124) added that the principle of equity is the unique principle of Indonesia, without disregarding other principles in Civil Law and Common Law, because both of the principles have become the features of people's behaviour in Indonesia.

As a state occupied mostly by Moslems, the content of the contract in Indonesia is influenced by principles in Islamic law (Mardani, 2013, p. 20), i.e.

a. Principle of divineness;

b. Principle of prophecy;

c. Principle of worship;

d. Principle of permissibility;

e. Principle of freedom;

f. Principle of equality;

g. Principle of justice;

h. Principle of writing acceptability;

i. Principle of honesty;

j. Principle of willingness;

k. Principle of halal (lawfulness);

1. Principle of trustworthy.

Based on opinions obtained from various sources presented above, family principle was not found anywhere in other legal systems. It is understandable because family principle is the principle unique for Indonesia, so that it does not exist in other legal systems.

Principles in other systems, influenced by Civil Law, Common Law, and Islamic Law, might have similarity to a certain extent to family principle; however, they have dissimilar values. Therefore, those principles can be introduced into Indonesian legal system by focusing on the pillars of family principle, such as the principle of consensualism in civil law, which is a crucial principle to establish a contract. 
Consequently, theories suggested that family principle and other principles in laws regarding contracts be gradually synchronized. The overview of other principle implementations in other legal systems towards family principle is presented in the following figure.

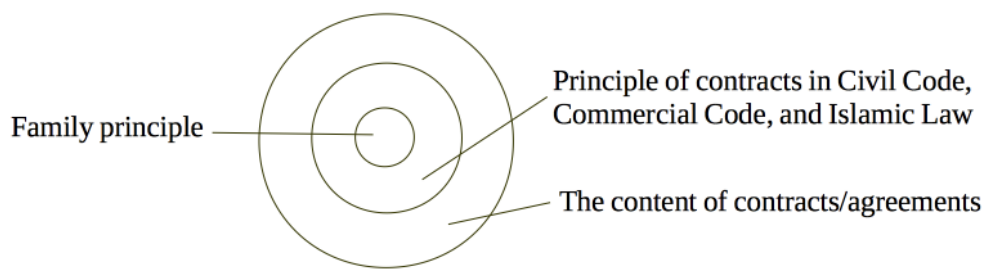

A legal system with family principle should be kept although other principles are included due to the influence of globalization. It is difficult for Indonesian people to abandon legal systems of continental Europe, Anglo-Saxon, and Islam because in terms of history and existing law, the norms from the three legal systems prevail in Indonesia(Prasetyo\& Purnomosidi, 2014, p. 3).

The family principle is located in the core of other principle implementations developed in a contract. Therefore, family principle shall be the primary principle which influences other principles. Other principles in laws are considered derivatives of family principle. The family principle is a guideline in running a business activity.

The principles from other legal systems as listed above in civil law resemble the second pillar of family principle, i.e. deliberation. However, the deliberation does not only intended to obtain shared ideas, but it also needs to help each other(Azhary, 2004, p. 98).

The presence of the value of deliberation gives a chance to disregard the principle of consensualism in establishing a contract because the principle focuses merely on agreement as values of consensus in philosophy of Dutch colonial law, which is capitalism and individualism. The principle of consensualism has become norms in Article 1339 of Civil Code allows obtaining mutual agreement as long as it does not contradict with laws, morality, and public order.

The concept was used by business players in establishing relationship with other business players and customers to rely on family principle. This suggests that family principle is treated as a guideline in establishing contracts between business players or with customers. Therefore, the implementation of family principle depends to great extent on legal culture of every business player(Raharjo, 1986, p. 82). When a business player refuses to integrate family principle, no law or regulation is violated.

The unavailability of law to impose family principle in making a contract shall nor be a reason to not following this principle. Business players are expected to adopt family principle as the state character in order to become a personal character in establishing contracts. The application of family principle shall be personal authority for legal subjects involved in business activities.

Contextually, personal characters should represent family principle. It shall always describe the character of the people, and it is the first step for Indonesian people to use family principle not only in written but also in practice. Sociologically, personal character of the people will become an indicator for establishing norms, because according to Manan(1994, p. 13), laws shall contain philosophical, juridical, and sociological foundations.

\section{CONCLUSION}

Family principle is a characteristic of Indonesian people which has become the guideline in running business activities. This principle contains two values as supporting pillars, i.e. deliberation and mutual assistance. The two pillars are inseparable and have to support each other for the welfare of Indonesian people. Therefore, the existence of other principles in laws regarding contracts, adopted from other legal systems, can be implemented in Indonesia as derivatives of family principle.

\section{REFERENCE}

[1] Arinanto, S., \& Triyanti, N. (2009). Memahami hukum dari konstruksi sampai implementasi [Understanding laws from construction to implementation]. Jakarta: RajaGrafindo Persada.

[2] Asshidiqie, J. (2010). Konstitusi ekonomi [Constitution in economy]. Jakarta: Kompas Penerbit Buku.

[3] Asshidiqie, J. (2014). Perihal undang-undang [About laws]. Jakarta: Rajawali Pers.

[4] Azhary, M. T. (2004). Negara hukum [Constitutional state]. Jakarta: Prenada Media.

[5] Badrulzaman, M. D. (1994). Aneka hukum bisnis [Various business laws]. Bandung: Alumni.

[6] Budiono, H., \& Moeliono, T. P. (2006). Asas keseimbangan bagi hukum perjanjian Indonesia: hukum 
perjanjian berlandaskan asas-asas wigati Indonesia [Principle of equity for laws regarding contracts in Indonesia: Contract laws based on principles of urgency in Indonesia]. Bandung: Citra Aditya Bakti.

[7] Dimyati, K. (2014). Pemikiran hukum [Philosophy of law]. Yogyakarta: Genta Publishing.

[8] Driyarkara. (1980). Tentang negara dan bangsa: Kumpulan karangan [About country and the people: Collection of papers]. Yogyakarta: Kanisius.

[9] Erawaty, E., Hardjowahono, B. S., \& Susanti, I. (2011). Beberapa pemikiran tentang pembangunan sistem hukum nasional Indonesia [Some thoughts on the development of Indonesian legal system]. Bandung: Citra Aditya Bakti.

[10] Gilsen, J., \& Gorle, F. (2005). Sejarah hukum: Suatu pengantar [History of law: An introduction]. Bandung: Refika Aditama.

[11] Hatta, M. (1979). Bung Hatta berpidata, Bung Hatta menulis [Hatta gave speeches, Hatta wrote. Jakarta: Mutiara.

[12] Hernoko, A. Y. (2010). Hukum perjanjian: Asas proporsionalitas dalam kontrak komersial [Contract laws: Principle of proportionality in commersial laws]. Jakarta: Kencana.

[13] Ibrahim, J. (2006). Teori dan metodologi penelitian hukum normatif [Theory and methodology of normative law researche]. Malang: Bayu Media.

[14] Kaelan. (2013). Negara Pancasila: Kultural, historis filosofis, yuridis, dan aktualisasinya [The state of Pancasila: Its culture, History, Philosophy, Jurisdiction, and Actualization]. Yogyakarta: Paradigma.

[15] Kartohadiprodjo, S. (2010). Pancasila sebagai pandangan hidup bangsa Indonesia [Pancasila as the way of life for Indonesian people]. Jakarta: Gatra Pusaka.

[16] Kusuma, A. B. (2004). Lahirnya Undang-Undang Dasar 1945: Memuat salinan dokumen otentik Badan Oentoek Menyelidiki Oesaha ${ }^{2}$ Persiapan Kemerdekaan [The establishment of the 1945 Constitution: Collection of copies of authentic documents from Indonesian Independence Preparations In. Depok: Badan Penerbit, Fakultas Hukum, Universitas Indonesia.

[17] Latief, J. A. (2012). Manusia, filsafat dan sejarah [People, philosophy, and history]. Jakarta: Bumi Aksara.

[18] Mahmud, Halim, A. A., \& Kattani, A. H. al. (2004). Akhlak mulia [Exemplary Behaviour]. Gema Insani Press: Jakarta.

[19] Manan, A. (2005). Aspek-aspek pengubah hukum [Aspects of law changes]. Jakarta: Kencana.

[20] Manan, B. (1994). Dasar-dasar konstitusional peraturan perundang-undangan nasional [Fundamental of constitutional laws and regulation]. Padang: Fakultas Hukum Universitas Andalas.

[21] Manan, B. (2013). Perekonomian nasional dan kesejahteraan sosial dalam UUD 1945 [National economy and social welfare in the 1945 Constitution]. Varia Peradilan, 33.

[22] Manan, B., \& Harijanti, S. D. (2014). Memahami konstitusi, makna dan aktualisasi [Understanding constitution, meaning, and actualization]. Jakarta: RajaGrafindo Persada.

[23] Mardani. (2013). Hukum perikatan syariah di Indonesia [Islamic law of obligation]. Depok: Sinar Grafika.

[24] Muhammad, A. (2010). Hukum perusahaan Indonesia [Corporate law in Indonesia]. Bandung: Citra Aditya Bakti.

[25] Muntaha. (2014). Penerapan asas oportunitas dalam hukum pidana di Indonesia [The implementation of oportunity principle in civil laws in Indonesia]. Yogyakarta: Genta Publishing.

[26] Notonagoro. (1975). Pancasila secara ilmiah populer [Pancasila in pupolar scientific version]. Jakarta: Pantjuran Tujuh.

[27] Oesman, O., \& Alfian. (1991). Demokrasi ekonomi: keterkaitan usaha partisipatif vs konsentrasi ekonomi [Economic democracy: Relation between participative business and economic concentration]. In Pancasila Sebagai Ideologi. Jakarta: BP 7 Pusat.

[28] Prasetyo, T., \& Purnomosidi, A. (2014). Membangun hukum berdasarkan Pancasila [Developing laws based on Pancasila]. Bandung: Nusa Media.

[29] Purnama, E. (2010). Identifikasi qanun Aceh dalam upaya menumbuhkan iklim usaha menuju demokrasi ekonomi berdasarkan Undang-Undang Dasar Tahun 1945 [Identification of Aceh Qanun in improving efforts for economic democracy based on the 1945 Constitution]. KANUN, 51, 465-476.

[30] Rahardjo, M. D. (2015). Arsitektur ekonomi Islam: menuju kesejahteraan sosial [Islamic economy architechture: towards social welfare] (1st ed.). Bandung: Mizan.

[31] Raharjo, S. (1986). Hukum dan masyarakat [Law and society]. Bandung: Angkasa.

[32] Ruslina, E. (2013). Dasar-dasar perekonomian Indonesia, dalam penyimpangan mandat Konstitusi UUD Negara Tahun 1945 [Fundamental of economy in Indonesia in irrelevancy with the 1945 Constitution]. Yogyakarta: Total Media.

[33] Suherman, A. M. (2012). Pengantar perbandingan sistem hukum [Comparative Introduction to legal systems]. Depok: PT. RajaGrafindo Persada. 
[34] Sundari, E. (2014). Perbandingan hukum dan fenomena adopsi hukum [Comparative law and law adoption phenomena]. Yogyakarta: Cahaya Atma Pustaka.

[35] Swasono, S. E. (1987). Sistem ekonomi dan demokrasi ekonomi [Economic system and economic democracy]. Jakarta: Universitas Indonesia (UI-Press).

[36] Syauki, T. (2011). Tafsir konstitusi berbagai aspek hukum [Constitutional interpretation of various legal aspects]. Jakarta: Kencana Prenada Media Group.

[37] Wahjono, P. (1989). Pembangunan hukum di Indonesia [Law developmen in Indonesia]. Jakarta: INDHILL- Co. 